\title{
Penerapan Hybrid Learning dalam Pembelajaran Pendidikan Agama Islam Kontekstual
}

\author{
Darul lailatul Qomariyah, M.Ag \\ Institut Agama Islam Riyadlotul Mujahidin Ngabar Ponorogo \\ laladarul@gmail.com
}

\section{Abstract}

The study is aimed to know how to implement Hybrid Learning in contextual Islamic studies learning in high school. Hybrid Learning means the measurable combination between in-person and distance learning. Contextual Islamic studies learning aims to facilitate the students to actualize and internalize the values contained in Islamic studies by learning experiences during the learning process. This study offers some steps to do to implement Hybrid Learning in contextual Islamic studies learning. The implementation of Hybrid Learning in contextual Islamic studies needs to be tested, observed, and evaluated to make it successful at the future.

Keywords: Hybrid learning, contextual, Islamic studies

\section{A. Pendahuluan}

Revolusi industri yang berlaku secara global dewasa ini membuat dunia pendidikan di Indonesia berupaya keras untuk segera menyesuaikan diri. Seluruh elemen pendidikan baik vertikal maupun horizontal berkolaborasi secara massive untuk merumuskan strategi dan konten pendidikan, termasuk di dalamnya pendidikan agama Islam, yang akan disajikan kepada peserta didik agar nantinya mampu memiliki skill abad 21 seperti yang dibutuhkan. 
Namun berbagai upaya keras yang dilakukan tersebut terhalang oleh adanya wabah Corona Virus yang melanda dunia, termasuk Indonesia. Kondisi yang tak disangkasangka ini berdampak pada dunia pendidikan di Indonesia, sehingga seluruh pemangku kepentingan di bidang pendidikan memutar otak lebih keras untuk mengupayakan proses pendidikan tetap berjalan, meskipun dalam masa pandemi. Berbagai kebijakan pemerintah di bidang pendidikan dikeluarkan demi penyelamatan generasi muda yang sedang menjadi pelajar saat ini, karena di tangan generasi muda inilah nasib negara akan ditentukan. Bahkan secara tegas Taufik Abdullah mengggambarkan betapa saratnya nilai yang di embankan pada generasi muda dengan embel-embel: "pemuda sebagai harapan bangsa", "pemuda adalah milik masa depan", atau "pemuda harus dibimbing" dan seterusnya. ${ }^{1}$ Oleh karena itu, pendidikan menjadi salah satu prioritas pemerintah di samping penyelamatan jiwa (kesehatan) dan ekonomi yang terdampak hebat.

Kebijakan menutup sekolah menjadi salah satu upaya pemerintah untuk menanggulangi semakin mewabahnya Corona Virus di Indonesia. Penyesuaian zonasi untuk pembelajaran tatap muka diberlakukan: status zona orange dan zona merah sama sekali tidak diperbolehkan menyelenggarakan pembelajaran tatap muka, wilayah dengan zona kuning dan hijau diijinkan untuk menyelenggarakan pembelajaran tatap muka dengan sistem bertahap mulai dari $50 \%$ di masa transisi. Tentunya kebijakan ini berpengaruh besar pada model dan proses pembelajaran siswa, terutama pembelajaran Pendidikan Agama Islam. Hampir seluruh pembelajaran diselenggarakan dengan moda daring (dalam jaringan),

Abdullah, T. \& Yasin, M. (eds) (1974) Pemuda dan Perubahan Sosial, LP3ES, Jakarta. 
meskipun ada pula yang kombinasi antara moda daring dan tatap muka (Hybrid Learning).

Pendidikan Agama Islam yang pada tataran regular disajikan melalui model pembelajaran aplikatif dan praktek, di masa pandemi ini para pelaku utama pendidikan (siswa dan guru) seakan bersaing untuk menggapai jalan terbaik untuk keberlangsungan proses pembelajaran. Meskipun sebenarnya sebelum masa pandemi pun para siswa dan guru telah mengenal tehnologi, namun mereka dipaksa untuk lebih akrab dengan berbagai alat dan aplikasi digital sebagai penunjang pembelajaran. Hal ini seakan menjawab apa yang dikemukakan oleh Hamza B. Uno dan Nina Lamatenggo dalam Budiman (2017) yang menyatakan bahwa kecenderungan pendidikan di Indonesia di masa mendatang akan banyak diwarnai modus belajar jarak jauh (distance learning), kerja sama antar lembaga pendidikan dalam sebuah jaringan perpustakaan dan instrumen pendidikan lainnya, dan penggunaan perangkat teknologi informasi interaktif. $^{2}$

\section{B. Memahami Hybrid Learning}

Model Hybrid Learning yang mengkombinasikan antara pembelajaran tatap muka dan pembelajaran daring (dalam jaringan) telah diimplementasikan semenjak adanya tehnologi komputer. Model ini pada prinsipnya adalah memfasilitasi siswa untuk memahami dan menjelajahi masalah di dunia nyata melalui pengalaman belajar yang otentik dan difasilitasi dalam lingkungan belajar dalam

2 B. Uno, H.. (2010). Teknologi Komunikasi dan Informasi Pembelajaran. Jakarta: Bumi Aksara dalam Haris Budiman, Peran Teknologi Informasi dan Komunikasi dalam Pendidikan, Al-Tadzkiyyah: Jurnal Pendidikan Islam, Volume 8 No. I 2017. 
jaringan. $^{3} \quad$ Hybrid Learning dimaksudkan untuk menggabungkan manfaat dari pembelajaran jarak jauh dan tatap muka. Dalam hal ini, guru berperan sebagai fasilitator dengan mendampingi siswa bila diperlukan, dan berperan sebagai instruktur dengan memberikan pelajaran pelengkap yang berjalan beriringan dengan belajar daring siswa. Halverson, Graham, Spring, dan Drysdale (2012), mendefinisikan pembelajaran hybrid sebagai "desain (pembelajaran) yang beragam dan meluas yang menggabungkan bentuk tatap muka dan online". ${ }^{4}$

Sedangkan Qi dan Tian (2011) menjabarkan dengan lebih detail mengenai hal-hal yang seharusnya ada dalam Hybrid Learning, yaitu (1) gabungan antara pembelajaran kolektif dan individual, (2) gabungan antara media komunikasi online langsung dan tidak langsung, (3) gabungan antara belajar mandiri dan belajar kelompok, dan (4) gabungan antara belajar formal dan informal, kaitannya dengan pengaturan jam belajar. ${ }^{5}$ Wang, Fong, \& Zhang (2009) menambahkan mengenai salah satu keunggulan dari Hybrid Learning yang menggabungkan manajemen waktu yang unik dalam menyampaikan pendekatan instruksional, terutama melalui (a) pembelajaran melalui media komunikasi online langsung (synchronous) yang mirip dengan ruang kelas online yang dapat diajarkan dengan basis satu-ke-satu atau satu-ke-banyak atau (b) pembelajaran melalui media komunikasi online tak langsung atau

${ }^{3}$ Ellis, A.K. (2001). Teaching, Learning, and Assessment Together: The Reflective Classroom. London: Eye on Education.

${ }^{4}$ Halverson, L. R., Graham, C. R., Spring, K. J., \& Drysdale, J. S. (2012). An analysis of high impact scholarship and publication trends in blended learning. Distance Education, 33(3),381-413.

${ }^{5}$ Qi, L., \& Tian, A. (2011). Design and Application of Hybrid Learning Platform Based on Joomla. In M. Zhou, \& H. Tan (Eds.), Advances in Computer Science and Education Applications (pp. 549-556). 
berjangka (asynchronous) yang menyediakan platform yang ideal untuk pendekatan pembelajaran jarak jauh. ${ }^{6}$

Perbedaan pokok antara pembelajaran konvensional dengan Hybrid Learning adalah kehadiran siswa di satu tempat belajar yang menjadi tuntutan bagi pembelajaran konvensional, sedangkan Hybrid Learning tak terlalu kaku. Hybrid Learning yang menggabungkan antara informasi dan komunikasi lebih memodifikasi bentuk pembelajaran dengan penerapan sistem pengajaran yang dapat dimengerti dan memanfaatkan berbagai piranti yang cerdas pula (seperti pengajaran kolaboratif, web interface, dan lain-lain) yang diyakini mampu mengenali berbagai kesulitan belajar siswa dan membuat metode pembelajaran menjadi makin variatif. Anastasiades dan Retalis (2002) mengungkapkan bahwa di dalam Hybrid Learning (1) ada perubahan peran antara siswa dan guru, (2) guru berubah menjadi pengkoordinir sumber-sumber belajar yang dapat memecahkan masalah dan mengolah pikiran siswa secara mandiri, (3) kehadiran fisik siswa dan persyaratan ujian digantikan dengan partisipasi aktif siswa dalam proses pembelajaran, pengembangan wilayah individualitas siswa, dan sistem evaluasi dua arah, (4) alokasi waktu proses pembelajaran berubah menjadi berusaha belajar seumur hidup. ${ }^{7}$

Mengenai keunggulan Hybrid Learning, beberapa penelitian menemukan bahwa Hybrid Learning dapat meningkatkan hasil belajar sekaligus meningkatkan

${ }^{6}$ Wang, F. L., Fong, J., Zhang, L., \& Lee, V. S. (2009). Hybrid Learning and Education. 2nd International Conference.

${ }^{7}$ Anastasiades, P. S., \& Retalis, S. (2002). The Educational Process in the Emerging Information Society: Conditions for the reversal of the linear model of education and the developmentof an open type Hybrid Learning environment. CSS Journal, 10 (1), 1-7. Retrived from http://users.softlab.ece.ntua.gr/ retal/papers/JOURNALS/CCS/Paper_ CCS.pdf 
hubungan komuniksi pada tiga moda pembelajaran, yaitu lingkungan pembelajaran berbasis ruang kelas tradisional, yang hybrid (campuran), dan yang sepenuhnya online. Bukti itu ditunjukkan salah satunya oleh Dziuban, Hartman, dan Moskal (2004) yang menemukan bahwa Hybrid Learning memiliki potensi untuk meningkatkan hasil belajar siswa dan juga menurunkan tingkat putus sekolah dibandingkan dengan pembelajaran yang sepenuhnya pembelajaran online. ${ }^{8}$

Adapun komposisi Hybrid Learning bervariasi, namun yang sering digunakan adalah 50-50, artinya alokasi waktu terbagi menjadi $50 \%$ pembelajaran tatap muka dan $50 \%$ pembelajaran online. Pertimbangan untuk menentukan komposisi ini bergantung pada hasil analisa kompetensi yang ingin dicapai, tujuan mata pelajaran, karakterisitik siswa, interaksi tatap muka, strategi pembelajaran online atau kombinasi, lokasi tempat tinggal siswa, karkterisitik dan kemampuan guru, dan sumber daya yang tersedia.

Yang perlu menjadi pertimbangan lain dalam pelaksanaan Hybrid Learning adalah penyediaan sumber belajar yang memadai dan sesuai dengan karakteristik, minat, dan tingkat ketersediaan sarana prasarana yang dimiliki oleh siswa. Hal ini berkaitan dengan bahan ajar serta metode penyampaian materi yang akan disajikan. Dalam hal ini guru harus mempersiapkan skenario pembelajaran yang matang dengan menentukan mana aktifitas belajar yang dapat dilaksanakan secara tatap muka, dan mana yang lebih efisien dilakukan secara online. Tingkat kompleksitas materi, tujuan pembelajaran, dan

8 Dziubian, C., Hartman, J., \& Moskal, P.D. (2004). Blended Learning: Online Learning Enters the Mainstream. Retrieved January 4, 2019, from www.researchgate.net 
metode penyampaian menjadi acuan utama dalam penyusunan skenario pembelajaran Hybrid Learning.

\section{Pembelajaran Pendidikan Agama Islam Kontekstual}

Pembelajaran Pendidikan Agama Islam ditujukan untuk mengembangkan keimanan dan ketakwaan kepada Allah SWT, menanamkan akhlak mulia dan nilai ajaran Islam sebagai pedoman untuk mencapai kebahagiaan dunia dan akhirat, penyesuaian mental siswa terhadap lingkungan sosial fisik, perbaikan kelemahan-kelamahan dan kesalahankesalahan dalam keyakinan dan pengalaman ajaran agama Islam, serta pencegahan dari hal-hal negatif dalam berlaku dan berbudaya. Karena itu model pembelajaran Pendidikan agama Islam harus menekankan pada keterpaduan antara sekolah dan masyarakat. Guru Pendidikan agama Islam harus mampu mendorong dan memantau kegiatan kependidikan agama Islam yang dilakukan oleh siswa di dua lingkungan lainnya yaitu keluarga dan masyarakat. Hal tersebut ditujukan agar terjadi keselarasan dan kesesuaian sikap siswa yang bersifat statis dan konsekuen, dalam artian siswa bersikap dan berbuat baik tidak hanya di lingkungan belajar (sekolah) saja, namun perilaku baik itu juga ditunjukkan di lingkungan keluarga dan masyarakat.

Sesuai regulasi yang diberlakukan, guru harus memiliki beberapa aspek kompetensi dasar sesuai Undangundang Nomor 14 Tahun 2005 pasal 10 ayat (1) Tentang Guru dan Dosen, yaitu kompetensi pedagogik, kompetensi kepribadian, kompetensi sosial, dan kompetensi profesional. Untuk guru Agama Islam, berdasarkan Keputusan Menteri Agama Nomor 211 Tahun 2011 Tentang Standar Kualifikasi dan Kompetensi Guru, kompetensi tersebut ditambah kompetensi leadership dan kompetensi spiritual. Berbagai persyaratan tersebut dimaksudkan untuk memperbaiki 
kualitas pembelajaran di sekolah. Tak hanya itu, diperlukan inovasi dan kreatifitas dari guru untuk dapat menjadikan pembelajaran menjadi lebih menarik minat belajar siswa dan lebih meningkatkan kualitas dukungan sistem pendidikan. Salah satu yang kiranya penting dalam konteks ini adalah implementasi Pembelajaran Pendidikan Agama Islam kontekstual.

Dengan pembelajaran Agama Islam kontekstual ini guru dapat menghantarkan siswa tidak saja ke tahapan afeksi, tetapi juga psikomotor dengan mengangkat isu-isu dan berbagai permasalahan sosial keagamaan dan sosial kemasyarakatan yang kongkrit dan relevan dengan masa kekinian. Guru juga dapat terbantu dalam mengaitkan antara materi yang diajarkan dengan situasi dunia nyata siswa dan mendorong siswa membuat hubungan antara pengetahuan yang dimilikinya dengan penerapannya dalam kehidupan mereka di tengah keluarga dan masyarakat. Dalam konteks ini siswa perlu mengerti betul apa makna belajar, manfaat apa yang dipelajari untuk mereka, dan bagaimana mereka mencapainya. Dengan demikian siswa akan menyadari bahwa apa yang mereka pelajari akan berguna sebagai bekal hidupnya kelak.

Pembelajaran Agama Islam kontekstual ini dapat diimplementasikan dengan beberapa tahapan, yaitu konstruktivisme, bertanya, menemukan, masyarakat belajar atau kelompok belajar, pemodelan, refleksi, dan penilaian sebenarnya. Dalam pembelajaran Agama Islam kontekstual ini memungkinkan terjadinya beberapa bentuk belajar antara lain mengaitkan, mengalami, menerapkan, kerjasama, dan proses transfer. Mengaitkan merupakan inti dari konstruktivisme. Di tahap ini guru mengaitkan konsep baru dengan sesuatu yang telah dikenal oleh siswa. Mengalami adalah inti dari kontekstual di mana belajar akan terjadi 
lebih cepat pada saat siswa dapat memanipulasi peralatan dan bahan yang ada serta melakukan bentuk-bentuk penelitian yang aktif. Menerapkan konsep dilakukan siswa ketika ia melakukan kegiatan pemecahan masalah. Dalam tahap ini guru dapat memberikan latihan yang realistik dan relevan sebagai stimulus. Kerjasama antar siswa memungkinkan untuk mereka dapat memecahkan masalah yang kompleks dengan sedikit bantuan. Pengalaman kerjasama ini tidak hanya membantu siswa mempelajari bahan yang ada, namun juga konsisten dengan dunia nyata. Transfer ilmu akan terjadi pada saat guru membuat bermacam-macam pengalaman belajar dengan fokus pada pemahaman dan bukan hafalan.

\section{Skenario Hybrid Learning Pendidikan Agama Islam Kontekstual}

Penerapan Hybrid Learning pada pembelajaran Pendidikan Agama Islam belum begitu marak di lembagalembaga pendidikan keagamaan. Ada beberapa faktor yang mempengauhi, di antaranya masih ada stigma bahwa pembelajaran Pendidikan Agama Islam lebih baik dilaksanakan sesuai dengan normatifnya saja, seperti menghafal ayat-ayat dan hadis-hadis, membaca sejarah Islam, mempraktekkan gerakan-gerakan bersuci, sholat, dan semacamnya. Ada satu hal yang sering terlewatkan oleh para guru pengampu Pendidikan Agama Islam, yaitu aktualisasi dan internalisasi nilai-nilai yang terkandung dalam Pendidikan Agama Islam. Memang bukan hal yang mudah untuk membuat Pendidikan Agama Islam tetap aktual, relevan dan rasional mengikuti perubahan zaman sekaligus pola pikir generasi kekinian. Diperlukan usaha dengan berbagai model, strategi, dan trik untuk mengimplementasikannya. Salah satu upaya untuk itu, 
sesuai dengan masa pandemi ini, di mana pembelajaran dilaksanakan secara beragam (in-person, distance, hybrid) perlu diuji cobakan implementasi Hybrid Learning dalam pembelajaran Pendidikan Agama Islam kontekstual.

Untuk menerapkan Hybrid Learning dalam pembelajaran Pendidikan Agama Islam kontekstual diperlukan beberapa keputusan yang harus diambil oleh guru pengampu, yaitu:

1. Kuantitas materi yang akan diajarkan dengan sistem Hybrid Learning.

Jika ini adalah pertama kalinya, maka guru dianjurkan untuk memulai dengan sejumlah kecil materi dulu, jadi semacam uji coba untuk mengaplikasikannya dengan 1 bab dan 1 kegiatan belajar.

2. Pokok bahasan yang akan diuji cobakan dengan sistem Hybrid Learning.

Disarankan untuk memilih pokok bahasan yang berorientasi pada pengembangan diri karena pokok bahasan tersebut lebih menantang dari segi konsep dan lebih banyak muatannya. Diharapkan dengan pokok bahasan ini siswa dapat lebih termotivasi untuk belajar sendiri sesuai dengan kemandirian dan gaya belajarnya sehingga dapat menghasilkan peningkatan daya ingat dan belajar materi lebih banyak. Guru dapat memilih metode pembelajaran yang menarik dan dapat diterapkan pada sistem pembelajaran tatap muka. Dianjurkan untuk mengikuti tahapan-tahapan dalam model pembelajaran kontekstual.

3. Menentukan jumlah siswa dan siapa saja siswa yang akan menjadi kategori kelompok eksperimental dan kelompok kontrol.

Kelompok eksperimental adalah para siswa yang dijadikan sasaran uji coba, sedangkan kelompok kontrol 
adalah siswa-siswa yang tidak menjadi sasaran uji coba. Kelompok kontrol akan menjadi pembanding efektif tidaknya pelaksanaan uji coba Hybrid Learning.

4. Menentukan jenis latihan dan peralatan pendukung yang diperlukan.

Sebuah uji coba tak lepas dari latihan, seperti halnya ketika siswa akan di uji, maka ia memerlukan beberapa latihan. Guru juga sama, harus mampu menentukan jenis latihan apa yang ia perlukan agar dapat menerapkan Hybrid Learning dengan baik. Latihan tersebut dapat dilaksanakan mandiri ataupun dengan mengambil beberapa kursus singkat.

5. Memperkirakan waktu yang dibutuhkan untuk mendesain pembelajaran model Hybrid Learning pada pokok bahasan yang akan diuji cobakan.

Tidak perlu terburu-buru untuk menerapkan Hybrid Learning, karena penerapan Hybrid Learning membutuhkan perencanaan yang matang terkait tujuan, materi, alokasi waktu, strategi/tehnik, sekaligus evaluasinya. Guru dapat memperkirakan waktu untuk menyususn semua perencanaan itu sekitar 2-3 minggu.

6. Menentukan kegiatan apa yang akan diberikan dalam pembelajaran tatap muka dan online.

Yang harus dimengerti adalah kegiatan belajar yang diberikan baik tatap muka maupun online bersifat integratif dan saling melengkapi. Apa yang dialami siswa pada pembelajaran tatap muka harus mendukung kegiatan yang dialami siswa pada saat pembelajaran online.

7. Menentukan sistem evaluasi dan penilaian dalam Hybrid Learning yang diberlakukan.

Guru dapat memilih jenis evaluasi yang paling tepat berdasarkan tujuan dan kedalaman serta keluasan materi. Pertimbangkan juga pengalaman belajar yang telah 
direncanakan untuk diberikan kepada siswa. Evaluasi ini dapat diselenggarakn secara tatap muka ataupun menggunakan aplikasi online yang tersedia.

8. Menentukan mekanisme pembentukan kelompok belajar (learning community).

Ada beberapa tehnik yang dapat diaplikasikan untuk membentuk kelompok belajar, misalnya papan diskusi di mana para siswa akan saling menunjukkan dan mengomentari profil masing-masing, membagi kelas menjadi beberapa kelompok, atau membuat kelompok diskusi.

Secara implementatif, Hybrid Learning hanya melakukan pembelajaran tatap muka ketika diperlukan saja, yaitu di awalawal pertemuan sebagai sarana orientasi tujuan pembelajaran, pengenalan konsep, dan pembentukan learning community. Selebihnya pembelajaran tatap muka dilakukan untuk memfasilitasi setiap permasalahan yang dihadapi siswa selama proses belajarnya. Ada dua alternatif mekanisme yang dapat diterapkan:

1. Jika diasumsikan dalam 1 semester ada 5 bulan efektif, maka pertemuan tatap muka diselenggarakan pada 2 bulan awal semester. Pada pertemuan tatap muka ini dimaksimalkan untuk orientasi tujuan pembelajaran dan pengenalan konsep beberapa materi sejenis sekaligus mekanisme pembentukan community learning sebagai landasan melakukan kegiatan belajar. Sisanya, 3 bulan pembelajaran dilaksanakan secara online, namun tetap dapat dilaksanakan tatap muka manakala sangat diperlukan.

2. Jika diasumsikan dalam 1 semester ada 3 pokok bahasan yang harus dipelajari, maka dapat terbagi menjadi masingmasing 2 bulan untuk tiap pokok bahasan. Dalam 1 pokok bahasan, pertemuan tatap muka diselenggarakan pada 2 minggu pertama, selebihnya diselenggarakan secara online. 


\section{E. Kesimpulan dan Saran}

Di saat seluruh elemen pendidikan baik vertikal maupun horizontal berkolaborasi secara massive untuk merumuskan strategi dan konten pendidikan guna menghadapi revolusi industry 4.0, upaya keras yang dilakukan tersebut terhalang oleh adanya wabah Corona Virus yang melanda Indonesia dan dunia. Kebijakan pemerintah menutup sekolah berpengaruh besar pada model dan proses pembelajaran siswa, terutama pembelajaran Pendidikan Agama Islam. Pendidikan Agama Islam yang pada tataran regular disajikan melalui model pembelajaran aplikatif dan praktek, di masa pandemi ini pembelajaran diselenggarakan dengan moda daring (dalam jaringan) ataupun kombinasi antara moda daring dan tatap muka (Hybrid Learning).

Penerapan Hybrid Learning pada pembelajaran Pendidikan Agama Islam belum begitu marak di lembagalembaga pendidikan keagamaan karena adanya beberapa faktor. Di samping itu, hal yang sering terlewatkan oleh para guru pengampu Pendidikan Agama Islam, yaitu aktualisasi dan internalisasi nilai-nilai yang terkandung dalam Pendidikan Agama Islam. Sebenarnya, proses aktualisasi dan internalisasi ini dapat dilakukan melalui pembelajaran kontekstual. Untuk itu menurut penulis perlu diujicobakan implementasi Hybrid Learning dalam pembelajaran Pendidikan Agama Islam kontekstual.

Untuk menerapkan Hybrid Learning ini disarankan bagi guru pengampu untuk berkoordinasi dengan pihak penentu kebijakan agar mendapat dukungan sistem sekolah, juga berkolaborasi dengan guru serumpun agar dapat terukur tingkat keberhasilan dari proses pembelajaran nantinya. 


\section{Referensi}

Abdullah, T. \& Yasin, M. (eds) (1974) Pemuda dan Perubahan Sosial, LP3ES, Jakarta dalam Suzanne Naafs \& Ben White, Generasi Antara: Refl eksi tentang Studi Pemuda Indonesia, JURNAL STUDI PEMUDA - VOL. I NO. 2 SEPTEMBER 2012, Hal: 89 -106.

Anastasiades, P. S., \& Retalis, S. (2002). The Educational Process in the Emerging Information Society: Conditions for the reversal of the linear model of education and the developmentof an open type hybrid learning environment. CSS Journal, 10 (1), 1-7. Retrived from http://users.softlab.ece.ntua.gr/ retal/papers/JOURNALS/ CCS/Paper_CCS.pdf

B. Uno, H. . (2010). Teknologi Komunikasi dan Informasi Pembelajaran. Jakarta: Bumi Aksara dalam Haris Budiman, PERAN TEKNOLOGI INFORMASI DAN KOMUNIKASI DALAM PENDIDIKAN, $\mathrm{Al}$ Tadzkiyyah: Jurnal Pendidikan Islam, Volume 8 No. I 2017.

Ellis, A. K. (2001). Teaching, learning, and assessment together: The reflective classroom. London: Eye on Education

Dziubian, C., Hartman, J., \& Moskal, P.D. (2004). Blended Learning: Online Learning Enters the Mainstream. Retrieved January 4, 2019, from www.researchgate.net.

Ellis, A.K. (2001). Teaching, Learning, and Assessment Together: The Reflective Classroom. London: Eye on Education.

Halverson, L. R., Graham, C. R., Spring, K. J., \& Drysdale, J. S. (2012). An analysis of high impact scholarship and publication trends in blended learning. Distance Education, 33(3), 381-413 
Qi, L., \& Tian, A. (2011). Design and Application of Hybrid Learning Platform Based on Joomla. In M. Zhou, \& H. Tan (Eds.), Advances in Computer Science and Education Applications (pp. 549-556).

Wang, F. L., Fong, J., Zhang, L., \& Lee, V. S. (2009). Hybrid Learning and Education. 2nd International Conference. 